\title{
INFLUENCE OF LAND USE CHANGE ON SEDIMENT YIELD: A CASE STUDY OF THE
} SUB-MIDDLE OF THE SÃO FRANCISCO RIVER BASIN

Doi:http://dx.doi.org/10.1590/1809-4430-Eng.Agric.v36n6p1005-1015/2016

\section{VICENTE DE P. R. DA SILVA ${ }^{1 *}$, MADSON T. SILVA ${ }^{2}$, ENIO P. DE SOUZA ${ }^{3}$}

${ }^{1 *}$ Corresponding author.Federal University Of Campina Grande/ Campina Grande - PB, Brazil. E-mail: vicente.paulo@.ufcg.edu.br

ABTSRACT: Erosion risk mapping and assessment are important for planning of natural resource management tool. The objective of this study was to simulate different scenarios of land use in the Sub-Middle of the São Francisco River Basin using the Soil and Water Assessment (SWAT) model to analyze the effects of changes in sediment yield, making comparisons with the present land use classification. The scenario analysis was (i) vegetation type characteristic of the semiarid region, (ii) growing corn and (iii) bare soil. For calibration procedure, the first three years of time series from 1993 to 1994 were validated using data from 1995 to 2004. The SWAT model employs the Modified Universal Soil Loss Equation (MUSLE) to compute soil erosion data. The results of simulations for different land uses allowed the identification of areas with a high potential for erosion by water. The major impact produced by sediment inflow was in the bare soil scenario, corresponding to an increase of $93.7 \%$ over the current land use. The landscape management in river basins using SWAT model can help identify areas particularly susceptible to erosion process.

KEYWORDS: hydrologic modeling, evapotranspiration, runoff, SWAT model.

\section{INTRODUCTION}

Studies of environmental impacts caused by human activities has attracted the interest of a large number of researchers to investigate new tools, including models that simulate alterations occurred by climate changes (SILVA et al., 2010; SOUSA et al., 2010) and by water and soil use (OEURNG et al., 2011). Hydrological models applied in river basins have been increasingly used to facilitate alternative water management and flood control (ARAGÃO et al., 2013; PEREIRA et al., 2014a; FUKUNAGA et al., 2015). One of the models most used worldwide for predicting soil erosion and transport of pollutants is the hydrosedimentological model Soil and Water Assessment Tool (SWAT). This is a model of water distribution to be coupled to a GIS interface; it considers the spatial variability of physical characteristics within a river basin. Several studies have applied this model to analyze the effects of land use changes on the hydrological flows in river basins (SETEGN et al., 2010; PEREIRA et al., 2014b; GALHARTE et al., 2014; SILVA et al., 2015). Nonetheless, SWAT may be unsuitable for simulations in small basins (KIM \& LEE, 2010). UZEIKA et al. (2012) also confirmed this fact when they applied this model to a small rural basin in the state of Rio Grande do Sul; the authors reported unsatisfactory results of sediment yield simulation if compared to the observed values.

The knowledge of land-use change effect on streamflow variation patterns helps devise strategies to minimize undesirable impacts of upcoming amendments (CIBIN et al., 2010). Conversely, as stated by HUNDECHA et al. (2008), little scientific information is found about quantitative relationships of land use properties with erosion generating mechanisms and sediment transport processes. Thus, mathematical models, such as SWAT, have major potential as a support tool for land-use planning, aiming to improve soil and water quality in river basins. The basic hypothesis is that sediment yield can be increased by changing soil use and, therefore, accelerating landscape degradation and desertification. In this sense, this study aimed to calibrate and validate the SWAT model to simulate the sediment input in the Sub-Middle São Francisco River Basin, under different land-use scenarios.

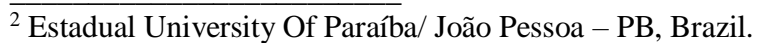

${ }^{3}$ Federal University Of Campina Grande/ Campina Grande - PB, Brazil 


\section{MATERIAL AND METHODS}

\section{Study area}

The study was carried out in the Sub-Middle São Francisco River Basin (BHSRSF, its acronym in Portuguese). It comprises areas in the states of Bahia and Pernambuco, with 110,446 $\mathrm{km}^{2}$, corresponding to $17 \%$ of the catchment area. The local climate is classified as tropical semiarid, with an annual average temperature around $26{ }^{\circ} \mathrm{C}$ and average annual rainfall of about 500 $\mathrm{mm}$. The rainy season is from November to April (SILVA et al., 2010). This drainage basin has great altitude variation, from a minimum of $173 \mathrm{~m}$ to a maximum of $1280 \mathrm{~m}$, and an average of $506 \mathrm{~m}$, within a range of $1,107 \mathrm{~m}$ (Figure 1A). These relief characteristics denote that certain regions of the basin would favor a large loss of water by runoff as a function of slope ramp. Areas at altitudes between 350 and 400 meters correspond to $17.605 \mathrm{~km} 2$, or $15.9 \%$ of the total area, being situated mainly within the central part of the basin, in the river channel. In contrast, altitudes between 400 and $450 \mathrm{~m}$ correspond to $24.705 \mathrm{~km} 2,22.4 \%$ of the total area. Moreover, areas above 450 meters account for more than $60.000 \mathrm{~km} 2$, i.e. $56 \%$ of the total basin area (SILVA et al., 2014).

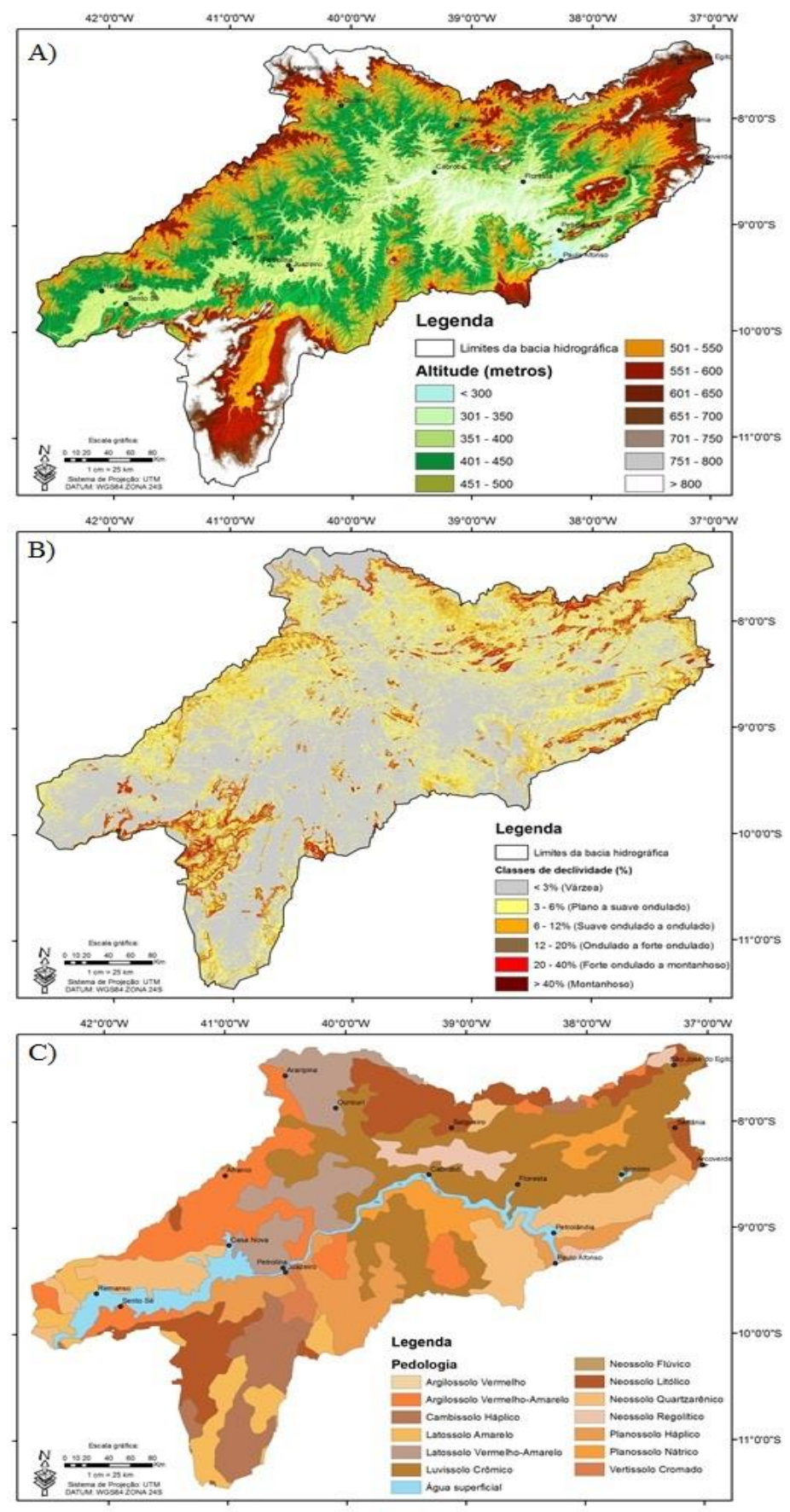

FIGURA 1. Hypsometric map (A), Slope (B) and Soils (C) of the BHSRSF for application in SWAT. 
The average slope of the BHSRSF was $4.4 \%$ (Figure 1B), over half of the area (83\%) show slopes below $6 \%$, which corresponds to floodplains and mildly hilly relief types, occupying more than $90.000 \mathrm{~km} 2$. Furthermore, there are slopes within a range 6 to $12 \%$, comprising 11,044 km2, i.e. $10.0 \%$ of the total area. This relief class includes areas with wavy and slightly wavy surfaces, where erosion risks are low and only conservation practices (tillage and contour) are required, except in erodible soils (sandy) with long ramp length (SILVA et al., 2014).

The basin presents predominance of three soil classes (Figure 1C), with over 26,463 km2 or $24 \%$ of the total area belonging to class Chromic Luvisol (Udalf). The second largest soil class is Red-Yellow Argisol (Ultisol or Alfisol), covering little more than 13,000 km2. The last class of soil is the Quartzipsamment (Entisol) comprising 11.1\% of the total area (SILVA et al., 2014).

\section{Hydrologic modeling using SWAT}

The SWAT model (Soil and Water Assessment Tool), which was designed to simulate the impact of farming activities on surface water quality (ARNOLD et al., 1998), integrated with the GIS tool, was applied in simulations of different land-use scenarios for the Sub-Middle São Francisco River Basin, as well as to verify the effects of these changes on sediment yield. In SWAT model, water production in a basin is estimated based on the water balance equation:

$$
S W_{t}=S W_{0}+\sum_{t=1}^{t}\left(P-Q_{\text {sup }}-E T-W_{a}-Q_{s u b}\right)
$$

In which,

$\mathrm{SW}_{\mathrm{t}}$ is the final water content in soil $(\mathrm{mm})$;

$\mathrm{SW}_{\mathrm{o}}$ is the soil water content available for plants, defined as the difference between the field capacity moisture content and the permanent wilting point $(\mathrm{mm})$;

$\mathrm{t}$ is the time (days);

$\mathrm{P}$ is the rainfall $(\mathrm{mm})$;

$\mathrm{Q}_{\text {sup }}$ is the surface runoff ( $\left.\mathrm{mm}\right)$;

ET is the evapotranspiration $(\mathrm{mm})$;

$\mathrm{W}_{\mathrm{a}}$ is the percolation $(\mathrm{mm})$, and

$\mathrm{Q}_{\text {sub }}$ return flow (capillary rise) (mm).

Potential evapotranspiration (ETp) was calculated by the Penman-Monteith method; for this, data from the rain gauge station of Bebedouro were used as a reference. Whereas the Linacre method was used in view of the availability of weather data in the other rain gauge stations within the study area. From potential evapotranspiration, actual evapotranspiration was estimated taking into account the evaporative demand of rainfall intercepted by vegetation, plant transpiration and soil evaporation (PERAZZOLI et al., 2013). Moreover, sediment yield derived from rain and runoff was estimated using the Modified Universal Soil Loss Equation (MUSLE), as follows:

$$
\text { sed }=11.8\left(Q_{\text {sup }} \times q_{\text {pico }} \times \text { Area }_{H R U}\right)^{0.56} \times K \times C \times L S \times P \times C F R G
$$

In which,

sed is the sediment yield after a rainfall event, in tons;

$\mathrm{Q}_{\text {sr }}$ is the surface runoff $(\mathrm{mm})$;

$\mathrm{q}_{\mathrm{rp}}$ is the peak runoff rate $\left(\mathrm{m}^{3} / \mathrm{s}\right)$;

Area $_{\mathrm{HRU}}$ is the are the Hydrologic Reseponse Unit (ha);

$\mathrm{K}$ is the soil erodibility factor $\left[\left(0.013 \mathrm{ton} / \mathrm{m}^{2} \mathrm{hr}\right) /\left(\mathrm{m}^{3} /\right.\right.$ ton $\left.\left.\mathrm{cm}\right)\right]$; 
$\mathrm{C}$ is the soil use and management factor (dimensionless);

LS is the topographic factor (dimensionless);

$\mathrm{P}$ is the factor of conservation practices (dimensionless), and

CFRG is the land fragmentation factor (dimensionless).

\section{SWAT operating procedure}

SWAT was performed from geospatial data entry and information uploading to store climatological and pedological database. Cartographic information and alphanumeric data were converted into ArcSWAT compatible format via appropriate interface (GIS). From the insertion of the Digital Elevation Model (DEM), the drainage system was outlined and, thus, allowing decomposition and discretization of the basin into sub-basins. Overlaying maps of land use and cover, soil and slope classes enabled forming the Hydrologic Response Units (HRUs); these, in turn, represent the information control units in SWAT model, both for parameterizations as for simulation output.

The model was fed daily and monthly weather data. Daily data comprised rainfall, maximum and minimum temperature, solar radiation, wind speed and air relative humidity; yet monthly ones consisted only of rainfall, maximum and minimum temperatures and air relative humidity. The data were gathered from meteorological stations Bebedouro, Cabrobó, Custódia, Ingazeira, Morro do Chapéu, Ouricuri, Petrolândia, Remanso and Verdejante, all distributed throughout the study area (Figure 2). The analyzed data series comprised from 1970 to 2010, belonging to the network of meteorological monitoring rain gauge stations of the National Institute of Meteorology (INMET). Streamflow data derived from stream gauge stations in the BHSRSF, being purchased from the National Water Agency (ANA) (Figure 2).

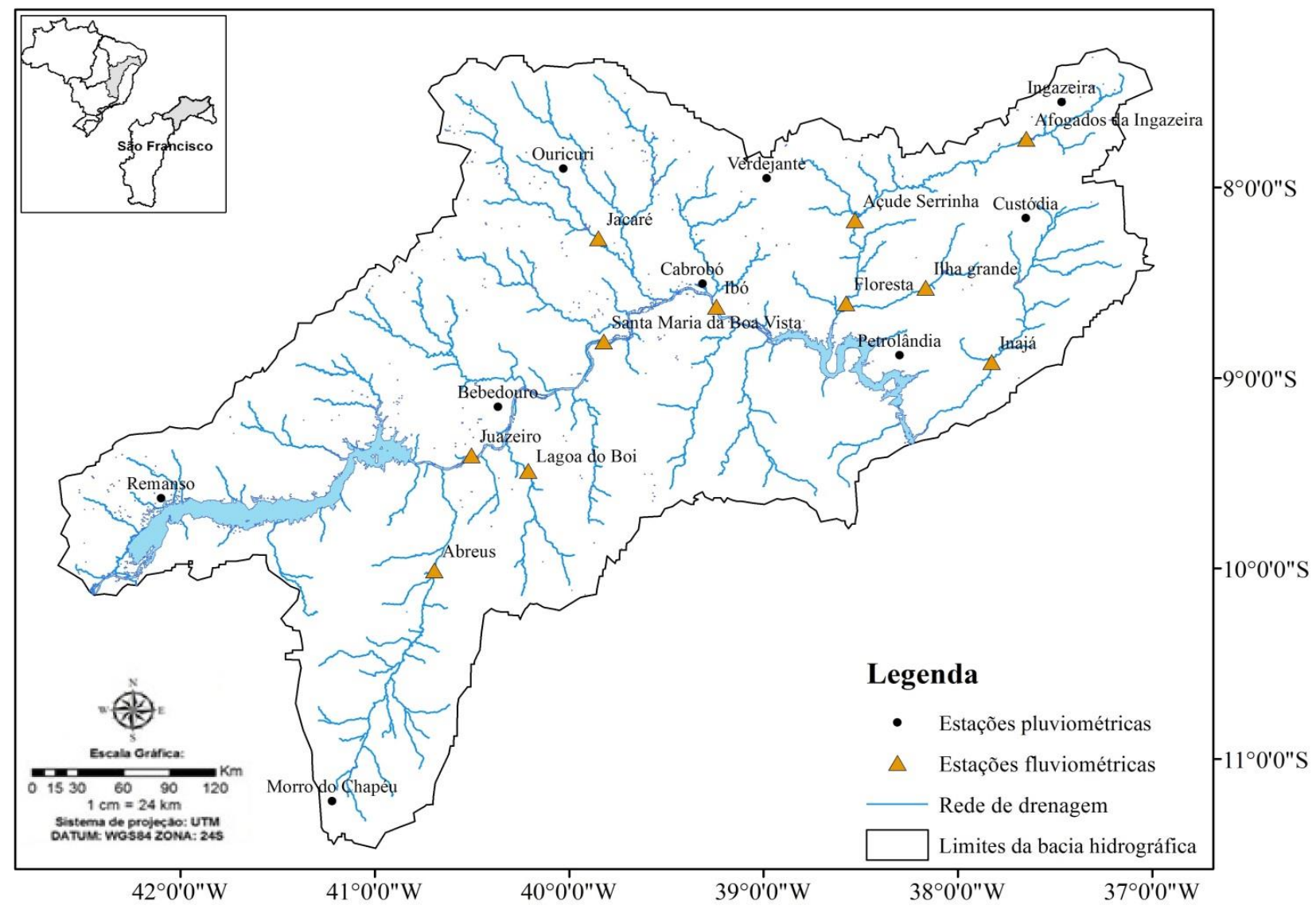

FIGURA 2. Weather and stream gauge stations localization in the Sub-Middle of the São Francisco River Basin. 


\section{Sensitivity analysis}

For the sensibility analysis, we used a combination of Latin Hypercube (LH) and One-FactorAt-a-Time (OAT) sampling techniques. LH was based on Monte Carlo method, enabling a robust sensitivity analysis, since it requires a great number of associated variables. The method subdivides the distribution of each parameter into $\mathrm{N}$ ranges, each with a probability of occurrence equals to 1/N. This sensitivity analysis played as a significant role in predicting the most influential parameters (Table 1) on hydrological and sedimentological simulations drawn directly by the ArcSWAT model (NEITSCH et al., 2005), rationalizing the time spent for calibration, and setting the parameters to which the model is less sensitive.

TABLE 1. Calibrating parameters of SWAT model.

\begin{tabular}{ll}
\hline Parameters & \\
\hline ALPHA_BF & Baseflow recession constant (days) or Baseflow alpha factor \\
BIOMIX & Biological soil mixing efficiency (Dl) \\
BLAI & Maximum leaf area index $\left(\mathrm{m}^{2}\right.$. $^{-2}$ ) \\
CANMX & Maximum water content intercepted by vegetation surface (mm) \\
CH_COV & Channel covering factor \\
CH_EROD & Channel erodibility factor \\
CH_K2 & Effective channel hydraulic conductivity (mm.h ${ }^{-1}$ ) \\
CH_N2 & Manning coefficient for the main channel (Dl) \\
CN2 & SCS curve number for moisture condition II (Dl) \\
EPCO & Plant evaporation compensation factor (Dl) \\
ESCO & Soil evaporation compensation factor (mm) \\
GW_DELAY & Groundwater delay (days) \\
GW_REVAP & Groundwater 'revap' coefficient (Dl) \\
GWQMN & Threshold depth of water in the shallow aquifer required for return flow to occur \\
RCHRG_DP & Fraction of Groundwater recharge to deep aquifer (Dl) \\
REVAPMN & Threshold depth of water in the shallow aquifer required for revap to occur (mm) \\
SLOPE & Sub-basin average slope (m.m $\left.{ }^{-1}\right)$ \\
SLSUBBSN & Sub-basin average slope length (m) \\
SOL_ALB & Soil albedo (Dl) \\
SOL_AWC & Available water capacity of the soil layer (mm.mm ${ }^{-1}$ ) \\
SOL_K & Soil saturated hydraulic conductivity (mm. ${ }^{-1}$ ) \\
SOL_Z & Depth from soil surface to the bottom of layer (mm) \\
SPCON & Linear parameter for calculating the channel sediment routing \\
SPEXP & Exponent parameter for calculating the channel sediment routing \\
SURLAG & Surface runoff lag coefficient (days) \\
USLE_C & USLE soil coverage factor \\
USLE_K & USLE soil erodibility factor \\
\hline
\end{tabular}

\section{Simulation scenarios}

Model warm-up period comprises the first three years of data series (1990-1992). Streamflow calibration and validation periods were between 1993 to 1994 and 1995 to 2004 for Abreus and Juazeiro gauge stations, respectively. This calibration was performed through an existing model self-calibration routine, considering the range of values of each parameter set by the sensitivity analysis and taken as the most significant ones.

Aiming to analyze how much land use and occupation alterations interfere with runoff processes and sediment yield, three scenarios were simulated from January 1993 to December 2010. In these simulations, we took as reference the use and coverage currently implemented in the BHSRSF, which will serve as the basis for comparisons with the scenarios. In the first scenario 
(scenario I) is proposed to replace the existing pasture by typical vegetation of caatinga (arboreal and sub-shrubby), simulating a conservationist context. Yet scenario II proposes to change the pasture by corn crop, performing a farming use. Finally, scenario III suggests the exchange of grazing areas for bare soil, viewing an environment degradation.

\section{RESULTS AND DISCUSSION}

Parameter ranking by sensitivity analysis improves the identification of most sensitive elements with significant influence on output data of streamflow and sediment yield simulations. This process makes the calibration more effective. The sensitivity analysis was based on results from the first simulations. As initial settings, streamflow data from Juazeiro gauge station were used. As a result, we identified 15 sensitive parameters associated with hydrological processes, and mostly related to surface and base runoff (Table 2). BALTOKOSKI et al. (2010) and LELIS et al. (2012) had already reported this trend.

TABLE 2. Sensitive parameters selected after sensitivity analysis.

\begin{tabular}{lccc}
\hline \multicolumn{1}{c}{ Parameter } & Min. & Max. & Process \\
\hline ALPHA_BF & 0 & 1 & Base runoff \\
CH_COV & 0.05 & 0.2 & Sediment yield \\
CH_EROD & 0 & 1 & Sediment yield \\
CN2 & -25 & 25 & Surface runoff and sediment yield \\
ESCO & 0.001 & 1 & Evapotranspiration \\
GW_DELAY & 1 & 500 & Base runoff \\
GW_REVAP & 0.02 & 0.2 & Base runoff \\
GWQMN & 0 & 5000 & Base runoff \\
SLOPE & -0.5 & 1 & Surface runoff \\
SLSUBBSN & -0.5 & 1 & Surface runoff \\
SOL_AWC & -0.5 & 2 & Base runoff and evapotranspiration \\
SOL_K & -0.5 & 1 & Base runoff \\
SURLAG & 1 & 16 & Surface runoff \\
USLE_C & 0 & 0.5 & Sediment yield \\
USLE_K & 0 & 0.5 & Sediment yield \\
\hline
\end{tabular}

Certain soil occupation characteristics may contribute significantly to sediment yield as their spatial distribution and predominance in each region. Hence, potential risks of degradation might present distinct values. For the land-use classes found in the Sub-Middle São Francisco River Basin (BHSRSF), under current conditions (Figure 3A), it is worth noting the prevalence of arboreal, shrubby and open-shrubby caatinga as well as grazing areas throughout the landscape; these areas cover $60,385.7 ; 18,998.5$ and $22,737.5 \mathrm{~km}^{2}$, respectively, totaling nearly $102,121.8 \mathrm{~km}^{2}(92.5 \%$ of the total). On the other hand, irrigated crops are found in the southern part of the basin, near the São Francisco River lowland, corresponding to $3,079.1 \mathrm{~km}^{2}$, i.e. less than $3 \%$ of the total area.

Scenario I (Figure 3B), vegetation recovery area, was shown as an alternative to reduce sediment delivery, bearing in mind the surface runoff decrease and increasing infiltration rates. In this scenario, sediment input declined to $110 \mathrm{t} \mathrm{ha}^{-1} \mathrm{yr}^{-1}$, portraying just over $86 \%$ of that of the current scenario. This result might have occurred due to surface condition changes, bolstering the importance of keeping areas under preservation with native vegetation. This finding corroborates that of ARAGÃO et al. (2013), which stated that areas of native or regenerated forests contribute to reducing soil breakdown by raindrop impacts, as well as surface runoff, thereby reducing sediment yield within this area. 

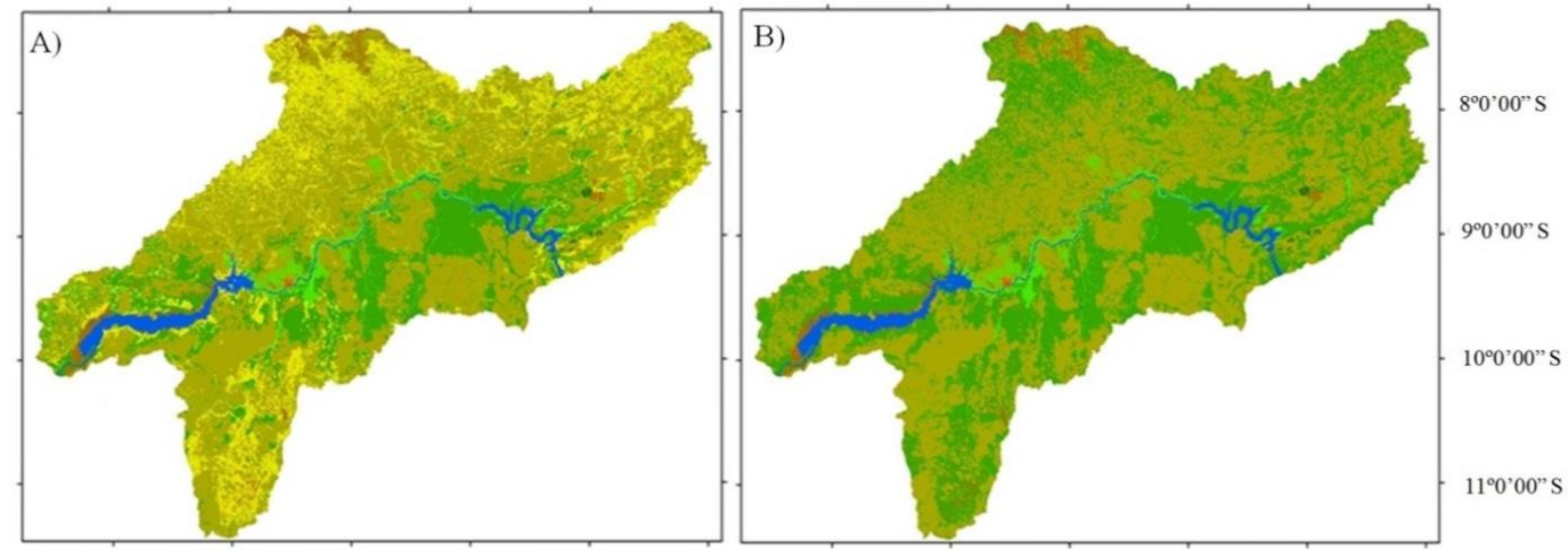

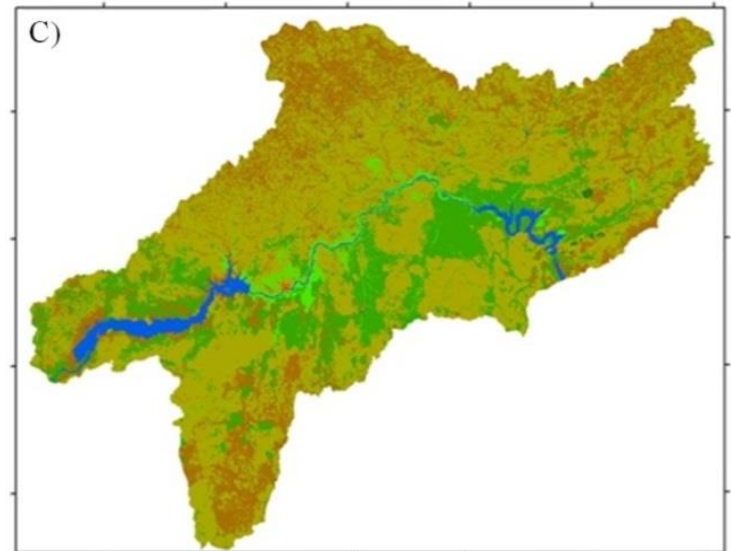

$42^{\circ} 0 " 00^{\prime \prime} \mathrm{W} 41^{\circ} 0 " 00^{\prime \prime} \mathrm{W} 40^{\circ} 0 " 00^{\prime \prime} \mathrm{W} 39^{\circ} 0 " 00^{\prime \prime} \mathrm{W} 38^{\circ} 0 " 00^{\prime \prime} \mathrm{W}$

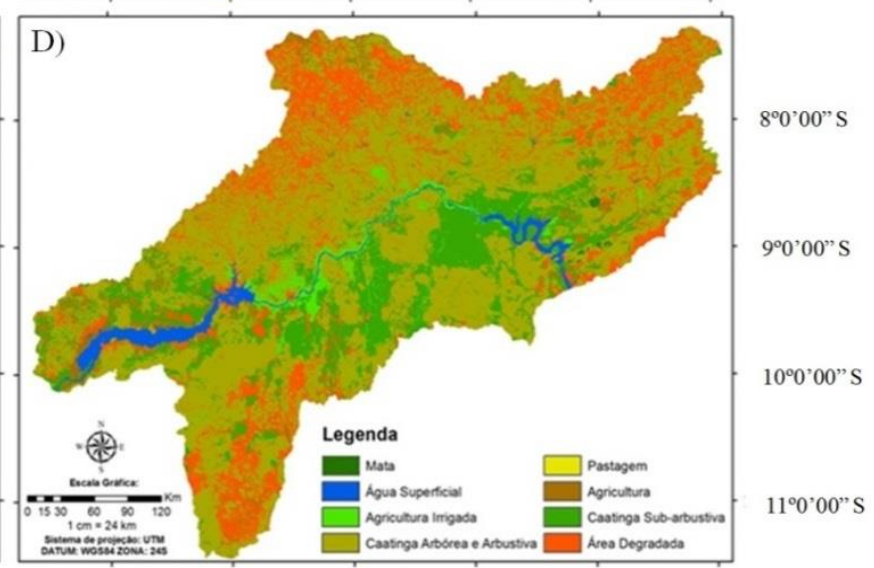

$42^{\circ} 0 " 00^{\prime \prime} \mathrm{W} 41^{\circ} 0 " 00^{\prime \prime} \mathrm{W} \quad 40^{\circ} 0 " 00^{\prime \prime} \mathrm{W} 39^{\circ} 0^{\prime \prime} 00^{\prime \prime} \mathrm{W} 38^{\circ} 0 " 00^{\prime \prime} \mathrm{W}$

FIGURA 3. Map of land use and occupation in the Sub-Middle of the São Francisco River Basin current conditions (A) under conditions of the scenario I (B) under conditions of scenario II (C) under conditions of scenario III (D).

Through scenario II, we could evaluate the human intervention impact by changing pasture for corn cropping (Figure 3C). If compared to scenario I, this exchange increased the drained volume on areas with patches of Chromic Luvisol (Udalf) and Red-Yellow Argisol (Ultisol or Alfisol).

The changes proposed for scenario III (Figure 3D), largely, affected the entire BHSRSF area. Areas classified as degraded under the current conditions of surface cover represented only 158.4 $\mathrm{km}^{2}(0.1 \%$ of the total area), whereas in the degradation scenario, this covering class represented $22,896.0 \mathrm{~km}^{2}$ (above $20 \%$ ).

In the current scenario of soil covering (Figure 4A), the northwestern region, which includes the Brígida River Basin, is one of the largest producers of sediment ( $>18 \mathrm{t} / \mathrm{ha}$ ), and showed levels in surface runoff well above average for the entire BHSRSF. Still we noted that low-risk areas prevail over the eastern portion of the basin, in the face of the topography ranging from flat to mildly hilly, which does not provide great volumes of surface runoff and eroded material carrying.

Surface runoff variation and land use changes between scenario I and the current ground covering also modified the feature related to sediment yield (Figure 4B). Scenario I produced significant reductions in sediment delivery in all BHSRSF sub-basins. Even though some regions have less significant reductions, the protective action exerted by vegetation significantly decreased the impact of raindrops on the soil, making it less prone to sediment supply to the drainage network. In this respect, MACHADO \& VETTORAZZI (2003) argued that the hydrological processes associated with land use and management clearly play a dominant role in sediment production and transport. Eventual differences among the pasture replacement scenarios are caused by factors related to the variability of evapotranspiration rates in the basin, as well as by changes in the infiltration and surface runoff promoted by each soil cover settings. In this respect, PEREIRA et al. 
(2014b) claimed that simulating different scenarios enabled the conclusion that deforestation brought evapotranspiration reduction and total runoff increase in the basin. Moreover, MELLO et al. (2008), using the SWAT model, observed serious impacts on the hydrological cycle of the Rio Grande River Basin, in the state of Rio Grande do Sul (Brazil), when pasture was replaced by eucalyptus due to an increase in evapotranspiration rate from eucalyptus plants.
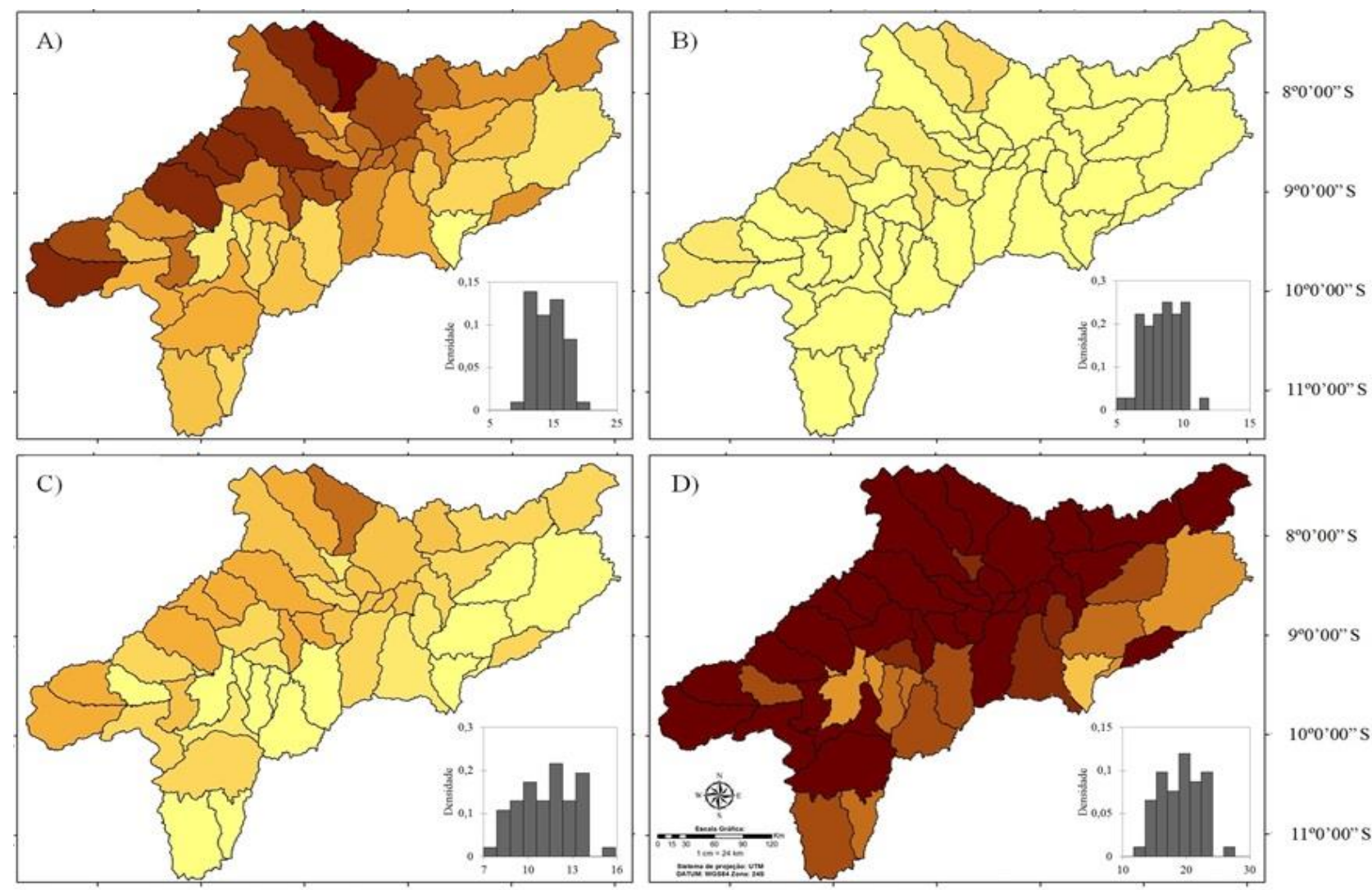

$42^{\circ} 0 " 00^{\circ}$ W $41^{\circ} 0 " 00^{\prime \prime}$ W $40^{\circ} 0 " 00^{\prime \prime}$ W $39^{\circ} 0^{\circ} 00^{\prime \prime}$ W $38^{\circ} 0^{\prime \prime} 00^{\prime \prime}$ W Legenda

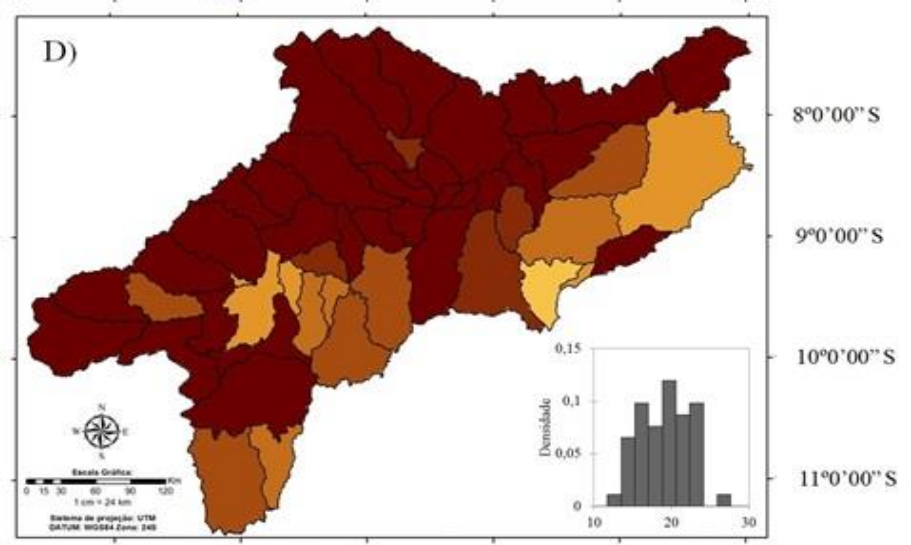

$42^{\circ} 0 " 00^{\prime \prime}$ W $41^{\circ} 0^{\circ} 00^{\prime \prime}$ W $40^{\circ} 0^{\circ} 00^{\prime \prime}$ W $39^{\circ} 0^{\circ} 00^{\prime \prime}$ W $38^{\circ} 0^{\circ} 00^{\prime \prime} \mathrm{W}$

$\square$ Limites das sub-bacias

Aporte de sedimentos (tha)

$\square<10 \square 11-12$

$10 \cdot 11 \square 12 \cdot 13$

$13-14$

$15-16$

$17 \cdot 18$

FIGURA 4. Average annual rates of sediment supply in the Sub-Middle of the São Francisco River Basin current conditions (A) conditions of the scenario I (B) under conditions of scenario II (C) under conditions of scenario III (D).

Proportions of sediment input for the agricultural use scenario has little spatial variation, as verified by (Figure 4C). The increase in sediment yield rates throughout the largest area of the basin is mostly due to the drainage volumes on the surface compared to scenario I. However, it is still substantially lower than that obtained in the current scenario (Figure 4A). This favors the detaching of soil particles by water flow shear stresses through the soil surface (PRUSKI, 2009). The particles are carried to the rivers, increasing the amount of sediment therein, featuring erosion processes. The sub-basins located in the northwestern part of the basin have rates higher than $15 \mathrm{t}$ ha- $1 \mathrm{yr}-1$, promoted by steep slopes together with litholic soils.

The trend of increasing steepness with larger sediment yields observed in some URHs here matches the findings proposed by MORGAN (1980), which emphasized that rising slopes are directly proportional to increasing runoff speed and, consequently, surface erosion ability. Within this subject, MARTINS FILHO et al. (2009) asserted that the vegetation plays an important role in controlling erosion and reducing the loss of organic matter and nutrients through sedimentation.

The absence of cover makes the erosion more eminent, mainly in regions where the rainy season is restricted to about 3 to 4 months a year. Erodibility and topographic factors still provide 
the willingness to sediment generation in scenario III (Figure 4D), increasing the degraded area within BHSRSF in $93.7 \%$, i.e., from 128 to $249 \mathrm{t} \mathrm{ha}^{-1} \mathrm{yr}^{-1}$. The responses of the model in function to the new layer of soil use evidence the increase in areas without any surface protection provided the identification of more sub-basins with surface runoff values exceeding $220 \mathrm{~mm} \mathrm{y}^{-1}$, in almost $50 \%$ of the basin. Considering that the rainfall patterns has undergone no changes, surface conditions have improved the transfer process of water flow from the rains. In this same line of research, PERAZZOLI et al. (2013) analyzed the effects of different land use scenarios on sediment yield in the Ribeirão Concordia River Basin, in the state of Santa Catarina (Brazil), and observed that the farming scenario showed the highest sediment production rate, being about 3 times larger than the current scenario. However, in the present study, the greatest sediment production rate was observed when replacing the grazing areas for bare soil.

The several soil types found in the BHSRSF yielded various substrates, i.e. responses to hydrosedimentological flows were also conditional upon vegetation cover and terrain slope. Water balance interferences of river basins can be noticed only by removing plant cover, in an unmanaged way, being thus one of the environmental degradation factors in semiarid regions. Moreover, the breaking of natural balance between the soil and the environment (removal of vegetation, diversion of freshwater courses, etc.), often promoted and sped up by the man action, exposes the soil less noticeable erosion forms, removing the surface layer and leaving the subsurface (usually less resistant) exposed to removing particles, resulting in appearance of gullies (DUQUE, 1980).

\section{CONCLUSIONS}

Land use changes have a significant impact on water availability in the basin. The simulation results in different land uses enabled us to identify areas with the greatest potential to water erosion. Replacing the grazing areas for corn cropping, simulating a farming scenario, constitutes a feasible alternative for maintenance of water production in the basin of the Sub-Middle of São Francisco River. Landscape management in river basins by means of the SWAT model can help distinguish areas where erosion control practices are necessary.

\section{REFERENCES}

ARAGÃO, R.; CRUZ, M.A.S.; AMORIM, J.R.A.; MENDONÇA, L.C.; FIGUEIREDO, E.E.; SRINIVASAN, S. Análise de sensibilidade dos parâmetros do modelo SWAT e simulação dos processos hidrossedimentológicos em uma bacia no agreste nordestino. Revista Brasileira de Ciência do Solo, Viçosa, MG, v.37, p.1091-1102, 2013.

ARNOLD, J.G.; SRINIVASAN, R.; MUTTIAH, R.S.; WILLIAMS, J.R. Large area hydrologic modeling and assessment. Part I: Model development. American Water Resources Association, Middleburg, v.34, p.73-89, 1998.

BALTOKOSKI, V.; TAVARES, M.H.F.; MACHADO, R.E.; OLIVEIRA, M.P. Calibração de modelo para a simulação de vazão e de fósforo total nas sub-bacias dos rios Conrado e Pinheiro Pato Branco (PR). Revista Brasileira de Ciência do Solo, Viçosa, MG, v.34, p.253-261, 2010.

CIBIN, R.; SUDHEER, K.P.; CHAUBEY, I. Sensitivity and identifiability of stream flow generation parameters of the SWAT model. Hydrological Processes, Chichester, v.24, p.11331148, 2010.

DUQUE, J.G. Solos e água no polígono das secas. 5. ed. Mossoró: Coleção Mossoroense, 1980. $273 \mathrm{p}$.

FUKUNAGA, D.C.; CECÍLIO, R.V.; ZANETTI, S.S.; OLIVEIRA, L.T.; CAIADO, M.A.C. Application of the SWAT hydrologic model to a tropical watershed at Brazil. Catena, Amsterdam, v.125, p.206-213, 2015. 
GALHARTE, C.A.; VILLELA, J.M.; CRESTANA, S. Estimativa da produção de sedimentos em função da mudança de uso e cobertura do solo. Revista Brasileira de Engenharia Agrícola e Ambiental, Campina Grande, v.18, p.194-201, 2014.

HUNDECHA, Y.H.; OUARDA, T.B. M. J.; BÁRDOSSY, A. Regional estimation of parameters of a rainfall-runoff model at ungauged watersheds using the "spatial" structures of the parameters within a canonical physiographic-climatic space. Water Resources Research, Washington, v.44, p.1427-1440, 2008.

KIM, N.W.; LEE, J. Enhancement of channel routing module in SWAT. Hydrological Processes, Chichester, v.24, p.96-107, 2010.

LELIS, T.A.; CALIJURI, M.L.; FONSECA, A. Análise de sensibilidade e calibração do modelo SWAT aplicado em bacia hidrográfica da Região Sudeste do Brasil. Revista Brasileira de Ciência do Solo, Viçosa, MG, v.36, p.623-634, 2012.

MACHADO, R.E.; VETTORAZZI, C.A. Simulação da produção de sedimentos para a microbacia hidrográfica do ribeirão dos Marins, SP. Revista Brasileira de Ciência do Solo, Viçosa, MG, v.4, p.735-741, 2003.

MARTINS FILHO, M.V.; LICCIOTI, T.T.; PEREIRA, G.T.; MARQUES JÚNIOR, J.; SANCHEZ, R.B. Perdas de solo e nutrientes por erosão num Argissolo com resíduos vegetais de cana-deaçúcar. Engenharia Agrícola, Jaboticabal, v.29, p.8-18, 2009.

MELLO, C.R.; VIOLA, M.R.; NORTON, L.D.; SILVA, A.M.; ACERBI JR, F.W. Development and application of a simple hydrologic model simulation for a Brazilian headwater basin. Catena, Amsterdam, v.75, p.235-247, 2008.

MORGAN, R.P.C. Soil erosion and conservation in Britain. Progress in Physical Geography, London, v.4, p.24-47, 1980.

NEITSCH, S.L.; ARNOLD, J.G.; KINIRY, J.R.; WILLIAMS, J.R. Soil and water assessment tool Theoretical Documentation, Version 2005. Texas, 2005.

OEURNG, C.; SAUVAGE, S.; SANCHEZ PEREZ, J.M. Assessment of hydrology, sediment and particulate organic carbon yield in a large agricultural catchment using the SWAT model. Journal of Hydrology, Amsterdam, v.401, p.145-153, 2011.

PERAZZOLI, M.; PINHEIRO, A.; KAUFMANN, V. Efeitos de cenários de uso do solo sobre o regime hídrico e produção de sedimentos na bacia do Ribeirão Concórdia-SC. Revista Árvore, Viçosa, MG, v.37, p.859-869, 2013.

PEREIRA, D.R.; MARTINEZ, M.A.; ALMEIDA, A.Q.; PRUSKI, F.F.; SILVA, D.D.; ZONTA, J.H. Hydrological simulation using swat model in headwater basin in southeast Brazil. Engenharia Agrícola, Jaboticabal, v.34, n.4, p. 789-799, 2014a.

PEREIRA, D.R.; ALMEIDA, A.Q.; MARTINEZ, M.A.; ROSA, D.R.Q. Impacts of deforestation on water balance components of a watershed on the Brazilian east coast. Revista Brasileira de Ciência do Solo, Viçosa, MG, v.38, p.1350-1358, 2014b.

PRUSKI, F.F. Conservação de solo e água: práticas mecânicas para o controle da erosão hídrica. 2. ed. Viçosa: UFV, 2009. 54p.

SETEGN, S.G.; SRINIVASAN, R.; MELESSE, A.M.; DARGAHI, B. SWAT model application and prediction uncertainty analysis in the Lake Tana Basin, Ethiopia. Hydrological Processes, Chichester, v.24, n.3, p.357-367, 2010. Disponível em: <http://dx.doi.org/10.1007/s10661-0080726-3>.

SILVA, V.P.R.; AZEVEDO, P.V.; SOUTO, B.R.; CAMPOS, J.H.B. Evaluating the urban climate of a typically tropical city of northeastern Brazil. Environmental Monitoring and Assessment, Dordrecht, v.161, p.45-59, 2010. 
SILVA, M.T.; SILVA, V.P.R; SOUZA, E.P. ; ARAÚJO, A. L. SWAT model application to estimate the flow in the basin of lower-middle São Francisco River. Revista Brasileira de Geografia Física, v. 8, p. 1615-1627, 2015.

SILVA, M.T.; SILVA, V.P.R.; SOUZA, E.P.; OLIVEIRA, V.G. Morphometric analysis of the basin low middle São Francisco river. Journal of Hyperspectral, Remote Sensing, Recife, v.4, n.8, p.168-174, 2014.

SOUSA, I.F.; SILVA, V.P.R.; AGUIAR NETTO, S.F.G.; SILVA, A.O.; SILVA, B.K.N.;

AZEVEDO, P.V. Evapotranspiração de referência nos perímetros irrigados do Estado de Sergipe. Revista Brasileira de Engenharia Agrícola e Ambiental, Campina Grande, v.14, p.633-644, 2010.

UZEIKA, T.; MERTEN, G.H.; MINELLA, J.P.G.; MORO, M. Use of the Swat Model for HydroSedimentologic Simulation in a Small Rural Watershed. Revista Brasileira de Ciência do Solo, Viçosa, MG, v.36, p.557-565, 2012. 